run the weapons laboratories, to make a new start in their efforts to improve both security and morale. "We realize that the way things are now is not going to work," says Marshall Combs, an adviser to energy secretary Bill Richardson. "This is going to be a new time. We are going to pull this off."

But researchers and managers at the DoE labs warn that rebuilding morale will be difficult. Los Alamos suffered another blow last week, with reports that senior staff there, including the director John Browne, will be disciplined by the University of California for their role in the harddrive incident. At the NAS meeting, ample evidence was presented of the toll the crisis is taking at its weapons labs as well as at the DoE's huge network of non-weapons labs.

Jonathan Dorfan, director of SLAC, which does no classified work at all, says the agency nonetheless faces "an unrelenting affront to the open research environment" characterized by "ill-conceived, one-sizefits-all directives". In June 1999, he says, there were 11 security directives pertinent to SLAC; now there are 31, with 21 more in draft. According to Ned Sauthoff of the Princeton Plasma Physics Laboratory, one draft asks researchers to get permission before making an international phone call.

Dorfan wants laboratories such as SLAC exempted from the rules. But

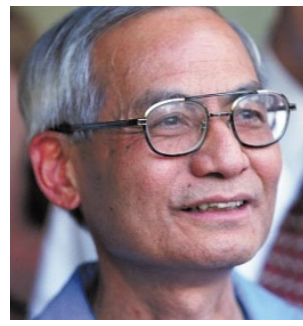

Lee: release from prison has prompted optimism. the case for exemption is complicated by the intermediate status of predominantly civilian laboratories such as Brookhaven in New York and Argonne in Illinois, which per-

form small amounts of classified work.

The best hope for a new beginning at the laboratory complex is perhaps the congressionally mandated NNSA, which has assumed responsibility for all of their nuclear weapons-related work. Will Happer, the Princeton University physicist and former assistant energy secretary, who organized last week's NAS meeting, predicts that the NNSA will prove effectiveonce it establishes autonomy on a par with that enjoyed, for example, by the National Institutes of Health within the health department. John Gordon - a former physics researcher and later a general in the Air Force - was appointed this summer as the NNSA's first administrator. Whereas other senior posts in the government will rotate after next month's elections, Gordon has been told by both political parties that he will serve for at least three years, ensuring continuity.

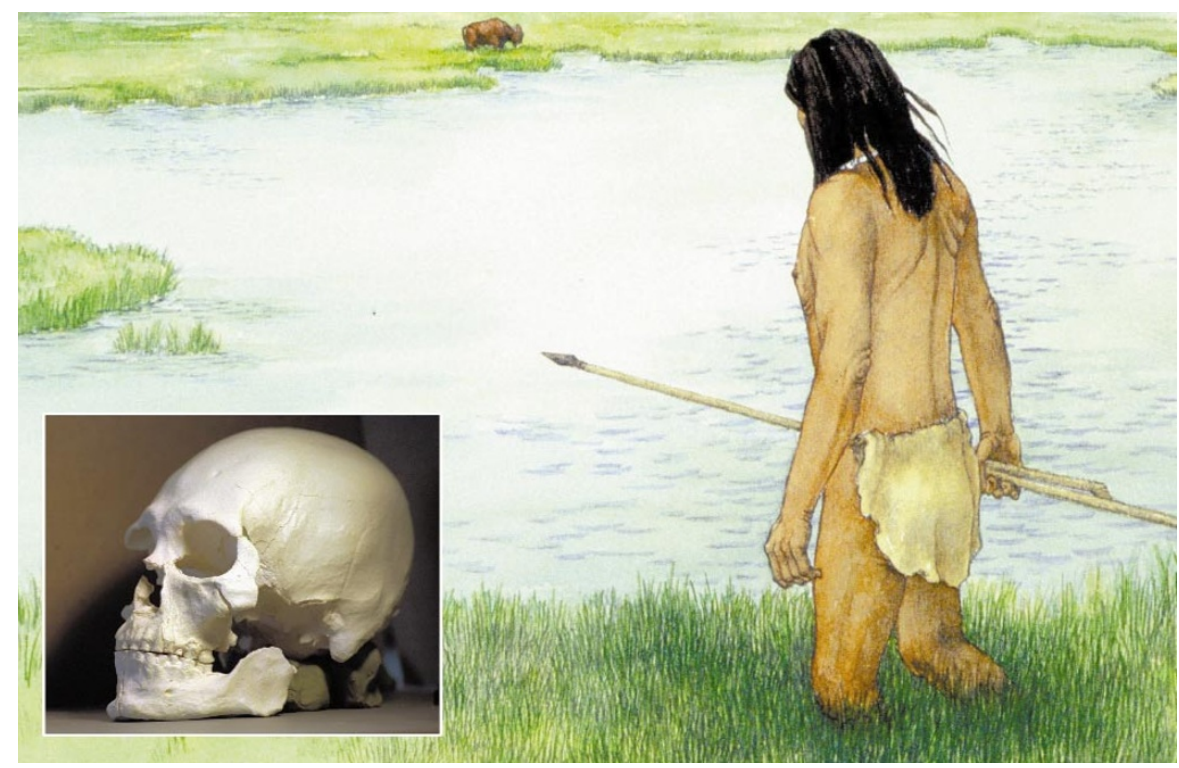

Culture clash: an artist's impression of Kennewick man, whose remains are caught up in a legal battle.

\title{
Researchers fight for access to Native American skeleton
}

\section{Rex Dalton}

Defiant researchers are taking the US government to court over its plan to return the much-debated 'Kennewick man' skeleton to Native American tribes for reburial.

Nearly four years ago, eight researchers sued the federal government to secure the right to study the ancient specimen, which was found in 1996 on federal land by the banks of the Columbia River near Kennewick, Washington.

But last week, after a procedural delay in the lawsuit, the US Department of the Interior ruled that the skeleton, which is $\mathbf{8 0 \%}$ complete, should be turned over to five Native American tribes for reburial. The decision was based on the Native American Graves Protection and Repatriation Act, which provides for the reburial of historic human remains.

The scientists now claim that the government is misinterpreting the law and blocking important research on one of the oldest and most intriguing specimens from the early peopling of the Americas, where only a dozen skulls over 8,000 years old have ever been found.

Partial analysis of the specimen indicates that it may be the remains of a man from Asia. The researchers want the legal right to examine the skeleton, and their lawyers will seek trial of the case at the US district court in Portland, Oregon.

Government lawyers declined to discuss the case, referring enquiries to the office of the interior secretary, Bruce Babbitt, where the decision was made. His spokeswoman, Stephanie Hanna, says Babbitt "feels all relevant evidence has been gathered" and that it shows "a cultural affiliation" to the tribes that desire reburial.

But the government's decision was branded as "ludicrous" by the archaeologist Robson Bonnichsen, director of the Center for the Study of the First Americans at Oregon State University and a plaintiff in the lawsuit. Bonnichsen wants access to the skeleton to study its bone mineralization.

The skeleton's age - estimated by radiocarbon dating at more than 9,300 years - means there is no way to link it to the specified Native American tribes.

For the Native American tribes in Washington and Oregon, however, the reburial of Kennewick man has become a symbol of control of historic human remains and of their legal rights. Armand Minthorn, board member of the Confederated Tribes of the Umatilla Indian Reservation, called the scientists' research plans "blatant desecration of sacred human remains".

Douglas Owsley of the Smithsonian Institution's National Museum of Natural History, says the lawsuit "is not against Native Americans". Owsley, who is suing as an individual, and biological anthropologist Richard Jantz of the University of Tennessee at Knoxville, another party to the suit, want to take 65 cranial measurements, comparing the resulting three-dimensional picture of the skull with a computerized database of 4,500 previously collected specimens.

The possibility of an amicable agreement to allow both study and reburial appears remote, with both sides accusing the other of unwillingness to negotiate. 